\title{
Transient G2M arrest and subsequent release of apoptotic and mitotic cells in vanadyl(4)-prepulsed human Chang liver cells
}

\author{
Kwok Hung Sit and De Lin Chen \\ Department of Anatomy, Faculty of Medicine, National University of Singapore, \\ Kent Ridge, Singapore 0511
}

Received 12.8.96; revised 30.9.96; accepted 21.10.96 Edited by M. Piacentini

\begin{abstract}
The relationship between cell cycling and apoptosis/ programmed cell death has been perceived as either checkpoint arrests or mitotic aberration where common pathways between mitosis and apoptosis seem suggested. We show here evidence implicating both perceptions of cell cycle involvement. The process was initiated by hydroxyl free radicals $\left(\mathrm{OH}^{\star}\right)$ generated intracellularly from internalized vanadyl(4). Intranuclear sequestration of vanadyl(4) was verified by nuclear microscopy. Resultant high oxidative reactivity in the nucleus was shown by the redox indicator methylene blue, suggesting direct oxidative damage to genomic DNA. Oxidative stress was further enhanced by depletion of glutathione which is the main cellular reducing agent. Genomic degradation and fragmentation was confirmed by flow cytometric evaluation of terminal deoxynucleotidyl transferase (TdT)-mediated $3^{\prime} \mathrm{OH}$ end-labelling (TUNEL) of DNA nicks, and cell cycle DNA profiling demonstrating subG1 (sub-2N) accumulation. With DNA degradation, there was a G2M transient with hyperdiploid right-shifting, consistent with G2 arrest. G2 arrest was subsequently' released' with abolition of G2M and all other cell cycle phases except for a solitary subG1 (apoptotic) peak. The cytological profile of this 'release' phenomenon was initially marked by the appearance of clusters of mitotic and apoptotic cells. At later stages, the cell population was composed exclusively of nuclear ghosts, apoptotic cells, mitotic cells, and mitotic cells with both chromosomes and apoptotic condensations. Concurrent and conjoint expression of cell death and cell division as the exclusive process of an entire cell population refuted the notion of mutual exclusivity between life and death. $\mathrm{Zn}^{2+}$, an endonuclease inhibitor, abolished all observed cytological and DNA profile changes.
\end{abstract}

Keywords: G2M apoptosis and mitosis, mitotic apoptosis, vanadyl(4), oxidative stress, population suicide

Abbreviations: $\mathrm{OH}^{\star}$, hydroxyl free radical; TUNEL, terminal deoxynucleotidyl transferase (TdT)-mediated dUTP nick end- labelling; V(4), vanadyl(4), vanadium ion with oxidative valence 4; $\mathrm{V}(5)$, dioxovanadium ion with oxidative valence 5; PIXE, particle-induced X-ray emission; RBS, Rutherford backscattering; STIM, scanning transmission ion microscopy; FBS, foetal bovine serum; DMEM, Dulbecco's modified Eagle's medium; $\mathrm{pH}_{\mathrm{i}}$, intracellular $\mathrm{pH}$; BCECF, 2',7'-bis(2-carboxyethyl)-5(and6)-carboxyfluorescein; GSH, glutathione, reduced form; MCB, monochlorobimane; GST, glutathione-S-transferase; PMT4, flow cytometer photomultiplier channel number 4 ; PI, propidium iodide

\section{Introduction}

Mitosis seems linked by morphological and molecular similarities with apoptosis (King and Cidlowski, 1995) the suicidal or programmed cell death implicated in tissue homeostasis and a host of hypo- and hyper-proliferative disorders including cancer (Thompson, 1995). Recent findings further suggest a functional linkage between cell proliferation and cell death. Inositol 1,4,5-trisphosphate $\left(\mathrm{IP}_{3}\right)$ receptor binding which triggers intracellular calcium accumulation and proliferation also triggers apoptosis (Khan et al, 1996). Oncogenic lesions that generate uncontrolled cell proliferation have been shown to be also potent triggers of apoptosis (Evan et al, 1995; Harrington et al, 1994; Gazitt and Erdos, 1994). Epidermal growth factor (EGF)-induced signal tranduction pathways that promote cell proliferation seem to mediate apoptosis as well (Reddy, 1996). Reactive oxygen species, either directly applied or generated via glucocorticoid hormones, are mediators of apoptosis and second messengers in cell proliferaion (Sundaresan et al, 1996; Fernandez et al, 1995; Briehl and Baker, 1996; Slater et al, 1996). However, while the signaling pathways for apoptosis and proliferation seem to be in common, concurrent cytological expressions in cell cycling have not been demonstrated as yet. Interphase checkpoint surveillance at $\mathrm{G} 1 / \mathrm{S}$ and $\mathrm{G} 2 / \mathrm{M}$ transitions are known to prevent cells with incomplete replication or unrepaired DNA damage from progressing into cytokinesis. The result of cell cycle transition arrest is phase-specific accumulations and mitotic depletion (Piacentini et al, 1993; Hartwell and Kastan, 1994; Earnshaw, 1995). Nevertheless, some cells have been noted to continue dividing despite cell cycle arrest in apoptotic systems (Traganos et al, 1992), and there have been arguments for the possibility that the interphase checkpoint surveillance could be bypassed allowing apoptosis to be committed with mitosis in common pathways (King and Cidlowski, 1995; Evan et al, 1995).

We have used vanadyl(4)-generated hydroxyl free radicals $\left(\mathrm{OH}^{\star}\right)$ to initiate apoptosis/programmed cell death in human Chang liver cells (Sit et al, 1996a,b). The advantage of this system is the ability to generate free 
radicals intranuclearly for direct DNA damage which is known to cause G2 arrest and accumulation. Here we studied the consequential phenomena in a time-response, demonstrating a transient G2 arrest followed by a 'release
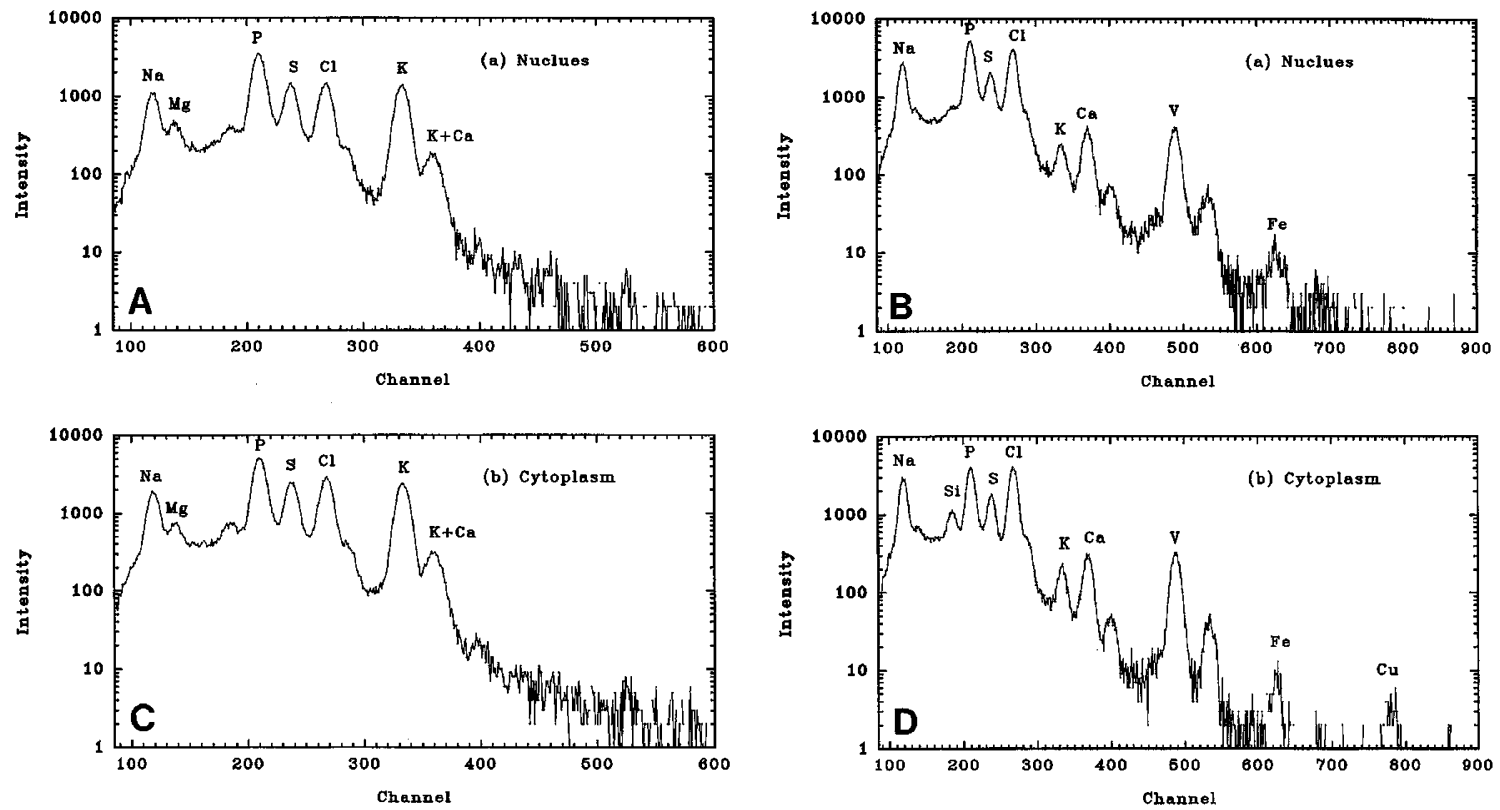

Figure 1 Quantitation of vanadium internalization by nuclear microscopy. Particle Induced X-ray Emission (PIXE) elemental spectra of a representative control (without V(4) prepulse) human Chang liver cell (A and C). No vanadium (V) peak is found in either (A) nucleus or (C) cytoplasm of the control. On the other hand, the vanadium peak $(\mathrm{V})$ is clearly evident $3 \mathrm{~min}$ after a $30 \mathrm{~min} \mathrm{~V}(4)$ prepulse $(B$ and $D)$. The $V(4)$ peak is higher in (B) the nucleus, than in (D) the cytoplasm. The calcium (Ca) peak is also raised.
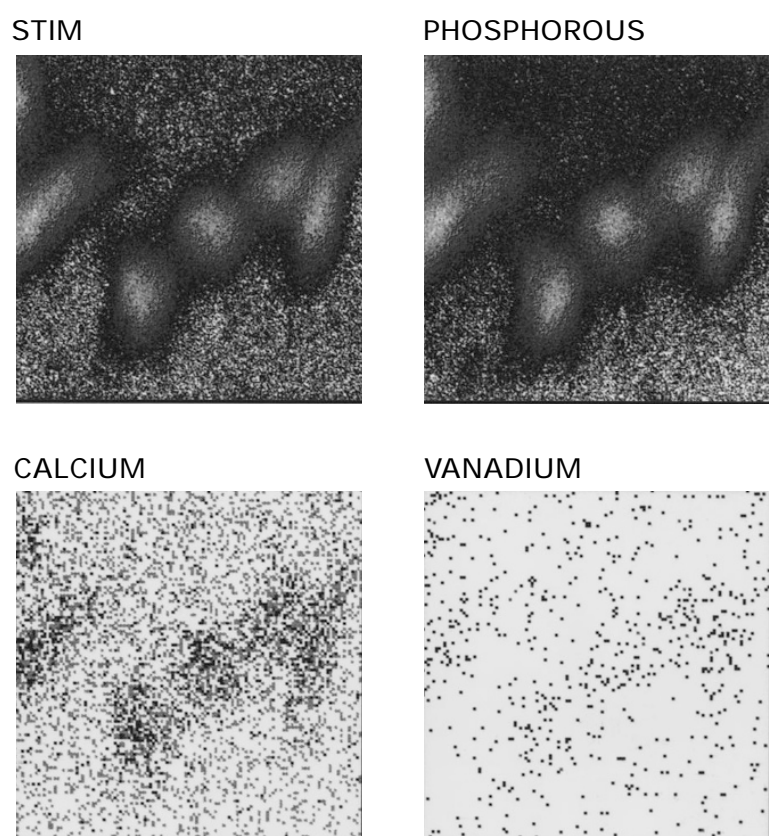

Figure 2 Cellular localization of vanadium in control cells by nuclear microscopy. Scanning Transmission Ion Microscopy (STIM) defined the cell and its nucleus which is outlined. Bitmapping of PIXE spectral energies shows the element phosphophorus having a high concentration in the nucleus, thereby helping to define the nucleus in conjunction with STIM. Calcium and vanadium elements are at low levels in the control cells.
STIM

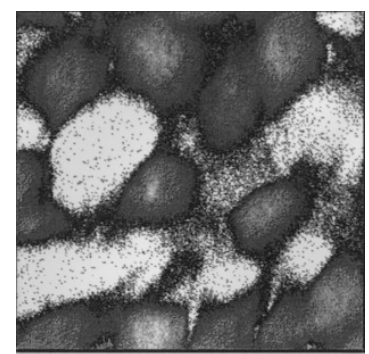

PHOSPHOROUS

\section{CALCIUM}
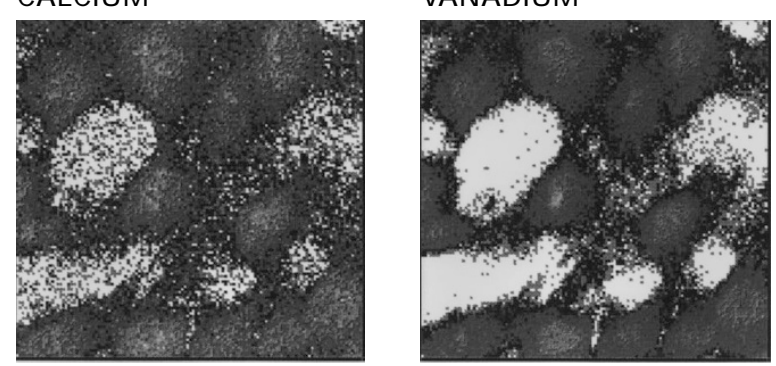

Figure 3 Cellular localization of vanadium in V(4)-prepulsed cells by nuclear microscopy. The nucleus is defined by STIM and PIXE bitmap of phosphorus. Here the cells are seen loaded with vanadium and calcium, concentrating particularly in the nucleus, the areas outlined by STIM and PIXE. 
phase' abolishing G2M and releasing not only apoptotic cells and nuclear ghosts, but also mitotic cells, and cells expressing both mitotic chromosomes and apoptotic condensations.

\section{Results and Discussion Vanadyl(4) internalization}

Hydroxyl radicals $\left(\mathrm{OH}^{\star}\right)$ were generated inside human Chang liver cells by inducing an intracellular loading of vanadyl(4), (V4), verified by nuclear microscopy (Figures 1-3). Nuclear microscopy incorporated (a) particle-induced X-ray emission (PIXE) to measure directly total (free and bound) elemental concentrations in the as-is state of single cells, (b) Rutherford backscattering spectrometry (RBS) which provided information on the matrix elements $\mathrm{C}, \mathrm{N}$ and $\mathrm{O}$, and (c) scanning transmission ion microscopy (STIM) which provided information on the structure and density to image the cell and its nucleus through transmitted proton energy loss (Sit et al, 1993). V(4) internalization was produced by a $30 \mathrm{~min}$ acidification prepulse in $\mathrm{V}(4)$ buffer, $\mathrm{pH} 5.5$. Following $\mathrm{V}(4)$ prepulsing the cells were reincubated in normal DMEM growth medium containing $10 \%$ FBS, for realkalinization back to
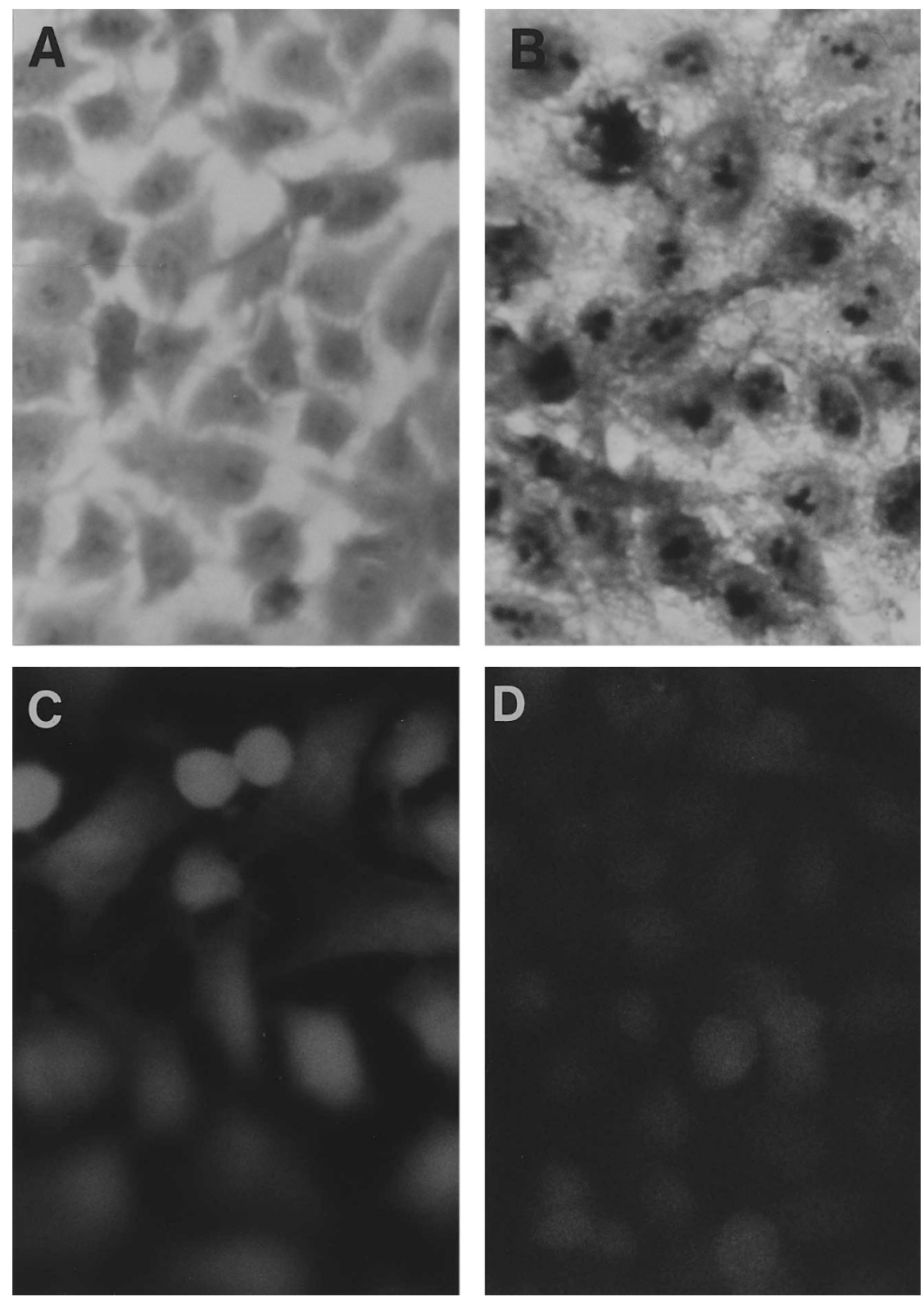

Figure 4 ( $A$ ) and (B) are the control and V(4)-prepulsed Chang liver cells, respectively, showing their oxidative states highlighted by the redox indicator methylene blue. Methylene blue is colourless in the reduced state but metachromatic (darker) when oxidized. The nuclei of $\mathrm{V}(4)$-prepulsed cells have high oxidative reactivity, suggesting direct oxidative damage to genomic DNA. (C) Glutathione (GSH) content of control cells, evaluated by GSH-monochlorobimane (MCB) adduct fluorescence at the excitation/emission wavelength of $395 / 470 \mathrm{~nm}$. (D) V(4)-prepulsed cells showing poor GSH-MCB fluorescence from GSH depletion. 
physiological levels. At $\mathrm{pH} 7$, the internalized $\mathrm{V}(4)$ readily converted with oxidation (even molecular oxygen) to $\mathrm{V}(5)$, the yellow dioxovanadium ions. In the $\mathrm{V}(4)$-to- $\mathrm{V}(5)$ conversion, superoxides were generated and these underwent spontaneous dismutation to form hydrogen peroxide (Hamada, 1994; Keller et al, 1988). Hydrogen peroxide and superoxides were sources of hydroxyl free radicals $\left(\mathrm{OH}^{*}\right)$ generated via the transition metal-ion driven Fenton and Haber-Weiss reactions (Halliwell and Gutteridge, 1984). An $\mathrm{OH}^{*}$ burst was triggered with realkalinization in normal growth medium after the $\mathrm{V}(4)$ prepulse (Sit et al, 1996a). $\mathrm{OH}^{*}$ could react with most cellular biomolecules of which DNA is a known target molecule (Farber et al, 1990). However the high reactivity of $\mathrm{OH}^{*}$ imposes strict limitations on its diffusion distance, estimated to be less than $7 \mathrm{~nm}$ from the site of generation (Byrnes, 1996). Thus unless $\mathrm{OH}^{*}$ was generated intranuclearly, it would be quite unlikely to have a direct effect on genomic DNA.

\section{Intranuclear oxidative damage}

High oxidative reactivity localized particularly in the nucleus after the $\mathrm{V}(4)$ prepulse was demonstrated by the redox indicator methylene blue which became a deep metachromatic (purple) colour from oxidation (Figure 4A and $B$ ). Methylene blue is colourless in the reduced state. The $\mathrm{OH}^{\star}$ burst (Sit et al, 1996a) coincided with depletion of glutathione (GSH), the main reducing agent of the cell (Figure 4C and D), thereby enhancing the oxidative stress. Flow cytometric cellby-cell evaluation of GSH content (measuring GSH-Monochlorobimane (GSH-MCB) adduct fluorescence) corroborated the cytological demonstration of GSH decline with realkalinization after a $\mathrm{V}(4)$ prepulse (Figure 5A). Without realkalinization, the $\mathrm{V}(4)$-prepulsed cells had $\mathrm{pH}_{\mathrm{i}}$ (intracellular $\mathrm{pH})=4.3$, and mean $\mathrm{GSH}-\mathrm{MCB}=226.9$ PMT4 channel units (Figure $5 \mathrm{~A}(\mathrm{i})$ ). $\mathrm{V}(4)$-prepulsed cells that had a $15 \mathrm{~min}$ recovery incubation in normal DMEM were realkalinized back to physiological levels $\left(\mathrm{pH}_{\mathrm{i}}=7.1\right)$ and overshot slightly the resting level (Figure 5A(ii)). At this realkalinized state, the mean $\mathrm{GSH}-\mathrm{MCB}=109.4$ units, representing a reduction by more than $50 \%$ of the original value. V(4)-prepulsed cells with a $2 \mathrm{~h}$ recovery in normal DMEM had $\mathrm{pH}_{\mathrm{i}}=6.9$ and mean $\mathrm{GSH}$ $\mathrm{MCB}=108.7$ units thereby indicating that $\mathrm{GSH}$ was already depleted to basal limits immediately upon realkalinization. GSH depletion coincided with (a) the triggering of an $\mathrm{OH}^{\star}$ burst from alkalinization of V(4) (Sit et al, 1996a), and (b) the demonstration of high oxidative reactivity in the nuclei (see Figure 4B). GSH depletion would enhance the oxidative stress, and contribute to the oxidative genomic damage (Kane et al, 1993; Dawson and Dawson, 1996). DNA fragmentation was confirmed by flow cytometric evaluation of specific terminal deoxynucleotidyl transferase (TdT)-mediated labeling of $3^{\prime} \mathrm{OH}$ ends of DNA breaks (Figure $5 \mathrm{~B}$ ).

\section{G2M transient and release sensitive to $\mathrm{Zn}^{2+}$}

Within 30 min after $\mathrm{V}(4)$ prepulsing, a significant increase in the proportion of cells in the G2M peak was detected (Figure $6 \mathrm{~A}(\mathrm{ii}) \mathrm{cf}$. Figure $6 \mathrm{~A}(\mathrm{i}))$. However this was associated with an obvious right-shifting of the peak suggesting cellular hyperdiploidy from G2 arrest blocking mitotic division (Figure $6 \mathrm{~A}(\mathrm{ii}-\mathrm{iv}))$. This was consistent with $\mathrm{G} 2$ accumulation due to G2/M transition arrest consequential to DNA damage from the $\mathrm{OH}^{*}$ burst released from internalized V(4). Concurrently there was sub-G1 accumulation. Cells with sub-G1 DNA were those having gross genomic DNA fragmentation with or without apoptotic chromatin morphologies (Tounekti et al, 1995). After

(A) (i) $\mathrm{V}(4)$ prepulsed: 0 min DMEM

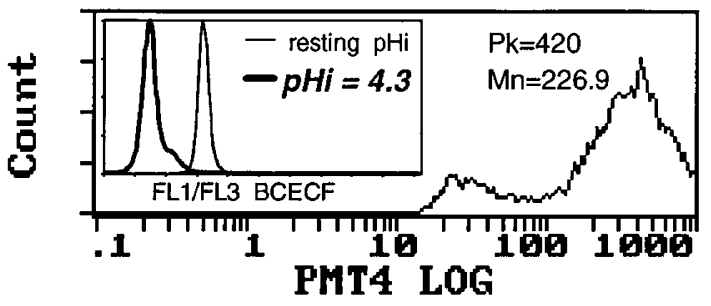

(ii) V(4) prepulsed: 15 min DMEM

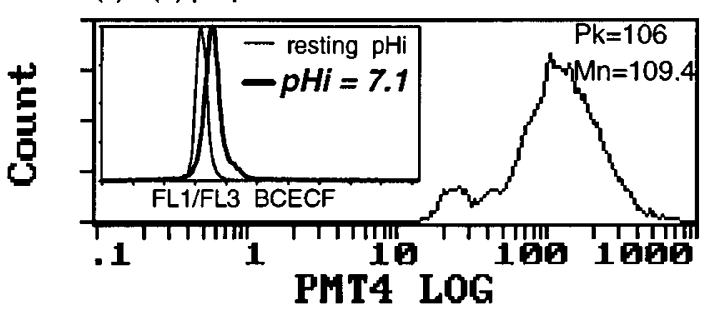

(iii) V(4) prepulsed: 2 hr DMEM

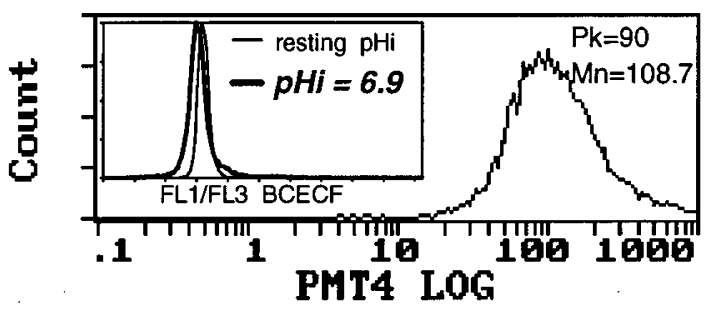

(B) DNA fragmentation

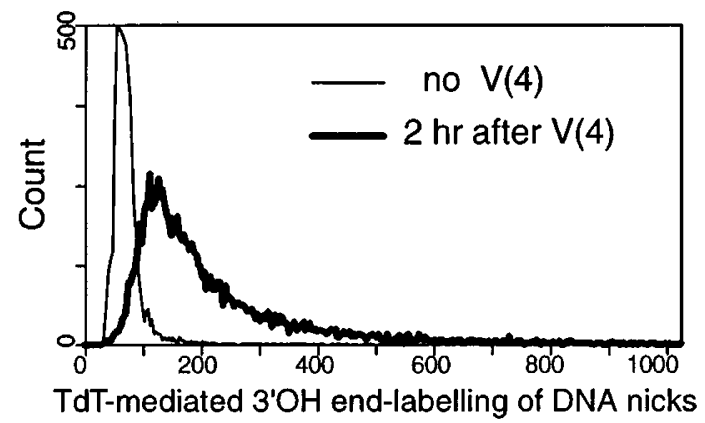

Figure 5 (A) Flow cytometric quantitation of GSH-MCB adduct fluorescence in a time-response after $\mathrm{V}(4)$ prepulse. Insets show the intracellular $\mathrm{pH}\left(\mathrm{pH}_{\mathrm{i}}\right)$ of cells at each stage, measured by ratiometric (FL1/FL3) BCECF evaluation in flow cytometry. GSH depletion to basal levels occured $15 \mathrm{~min}$ after V(4) prepulse. (C) Terminal deoxynucleotidyl transferase (TdT) mediated endlabeling of $3^{\prime} \mathrm{OH}$ ends of DNA fragments evaluated by flow cytometry confirms that genomic DNA fragmentation characteristic of apoptosis has occurred. 
$2 \mathrm{~h}$, the G2 arrest was 'released', as shown by reduction of the G2M peak. G2M flattened out by $4 \mathrm{~h}$ (Figure $6 \mathrm{~A}(\mathrm{v}))$. By $8 \mathrm{~h}$, the G2M became virtually abolished, while sub-G1 dominated as the only peak in the cell cycle (Figure $6 \mathrm{~A}(\mathrm{vi})$ ). Addition of $1 \mathrm{mM} \mathrm{ZnCl} 2$ (Figure 6B) into the incubations completely prevented any G2M accumulation or destruction. It also prevented sub-G1 accumulation and apoptotic condensations in cytological profiles.

\section{Cytological profile of 'release' from G2 arrest}

Release from G2 arrest produced mitotic and apoptotic cell clusters (Figure 7B). The cell suspension that gave the flow cytometry profile shown in Figure $6 \mathrm{~A}(\mathrm{v})$ produced the Cytospin cytological profile shown in Figure 7B. This contrasted with the control untreated profiles (Figures 7A and $6 \mathrm{~A}(\mathrm{i}))$ where neither mitotic nor apoptotic cells were prominent features. The mitotic figures however were not altogether normal. In the cluster of five mitotic cells (indicated by thin arrows in Figure $7 \mathrm{~B}$ ) one had a triradiate metaphase plate (arrow-(i)) and the other had disorientated chromosome distribution (arrow-(ii)). Intermingled with the mitotic cells were apoptotic cells with 'lumpy' apoptotic chromatin condensations (arrowheads). Fat arrow points to a dense 'single-ball' chromatin condensation which is also typical of apoptosis (Earnshaw, 1995). Even when genomic degradation had affected virtually the entire population (indicated by the solitary sub-G1 peak in Figure $6 \mathrm{~A}(\mathrm{vi}))$, there were mitotic cells accompanying apoptotic cells (Figure 7C). These cells were distinctively highlighted by their bright fluorescence while the rest of the cells were non-fluorescent ghost-like images from severe degradation. In addition, there were conjoint expressions of both mitotic chromosomes and apoptotic condensation in the same cell (Figure 7C, fat
(A) (i) No V(4) prepulse

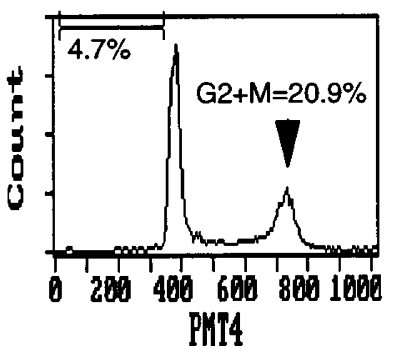

(iii) $1 \mathrm{hr}$ after prepulse

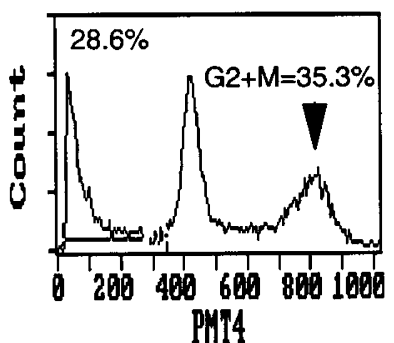

(v) $4 \mathrm{hr}$ after prepulse

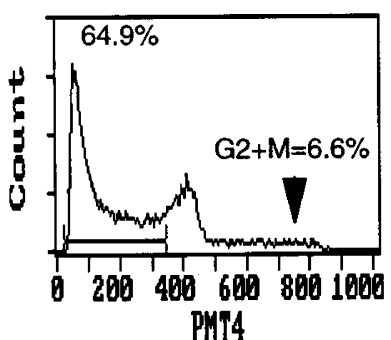

(ii) $0.5 \mathrm{hr}$ after prepulse

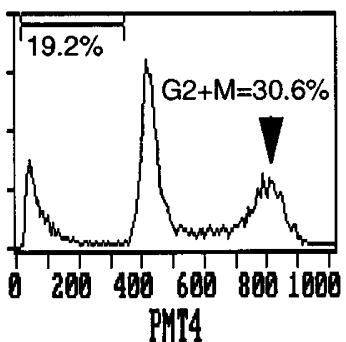

(iv) $2 \mathrm{hr}$ after prepulse

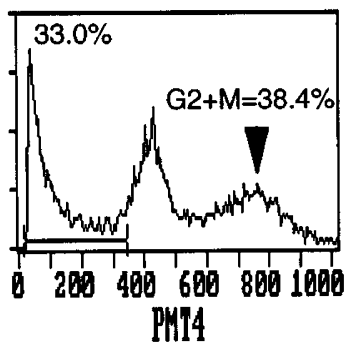

(vi) $8 \mathrm{hr}$ after prepulse

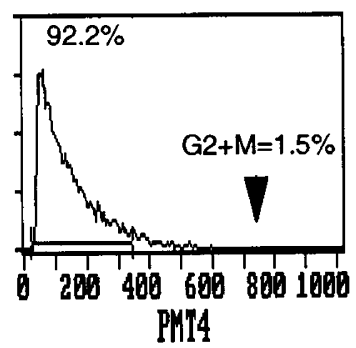

(B) (i) Zn(2): No V(4) prepulse

(ii) $\mathrm{Zn}(2): 0.5 \mathrm{hr}$ after prepulse
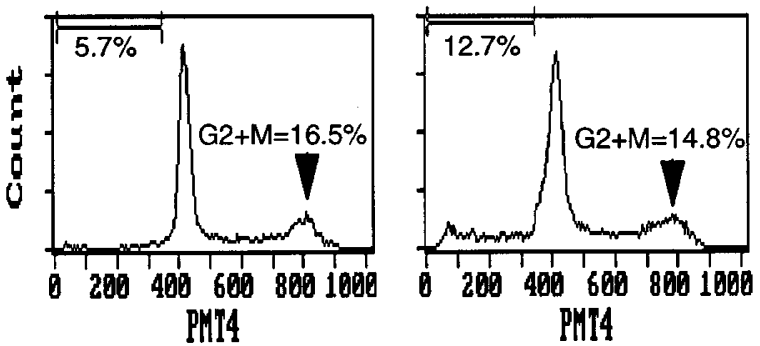

(iii) $\mathrm{Zn}(2): 1 \mathrm{hr}$ after prepulse

(iv) $\mathrm{Zn}(2): 2 \mathrm{hr}$ after prepulse
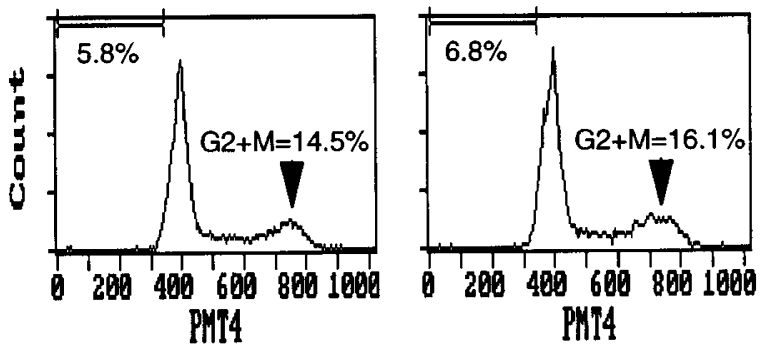

(v) $\mathrm{Zn}(2): 4 \mathrm{hr}$ after prepulse

(vi) $\mathrm{Zn}(2): 8 \mathrm{hr}$ after prepulse
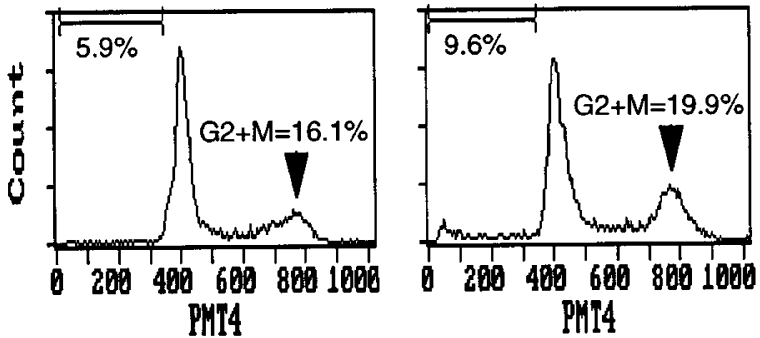

Figure 6 (A) Flow cytometric DNA cell cycle profiles of Chang liver cells in normal DMEM growth medium after a V(4) prepulse, in a time-response evaluated by the Multicycle DNA cell cycle analysis programme version 2.53 (Phoenix Flow Systems, Sorrento Valley, San Diego, USA). In the first $2 \mathrm{~h}$ after V(4) prepulsing, the G2M peak increased concomitantly with increase in the sub-G1 or apoptotic peak (A(i)-(iv)). Thereafter the G2M peak decreased and flattened out with continued sub-G1 accumulation which reached $92 \%$ of the population at $8 \mathrm{~h}$ after $\mathrm{V}(4)$ prepulsing $(\mathrm{A}(\mathrm{V})$-(vi)). (B) DNA cell cycle profiles of parallel cultures of Chang liver cells in DMEM growth medium supplemented with $1 \mathrm{mM} \mathrm{ZnCl}$, after a $\mathrm{V}(4)$ prepulse which also contained $1 \mathrm{mM} \mathrm{ZnCl}_{2}$ supplement. All profiles were normal. 
arrow). The presence of even a single mitotic cell in such devastated circumstances would be striking. Presence of clusters of these mitotic cells became therefore a stunning sight, providing irrefutable evidence of cell division occurring with cell death.

Mitotic cells have been noted in G2-arrested leukaemic HL-60 cells from genistein treatment, although they appear to be from continuing cell division because of surrounding normal cells (Traganos et al, 1992). In contradistinction, our mitotic cell clusters were in the exclusive company of either apoptotic cells or nuclear ghosts only (Figure 7C). The entire cell population at this stage did not have any normal cell that could sustain cell cycling. It was total population cell suicide with the paradoxical presence of mitotic cells, albeit not altogether normal. Mouse fibrosarcoma L929 cells and human leukaemic HL-60 cells have also been shown to undergo transient $\mathrm{G} 2$ arrests after $\gamma$-irradiation (Abend et al, 1996). There the release from $\mathrm{G} 2$ arrest is seen associated with either apopotosis or formation of micronucleated cells which must develop from aberrant mitosis, and suggests therefore a similar path of concomitant apoptosis and mitosis.
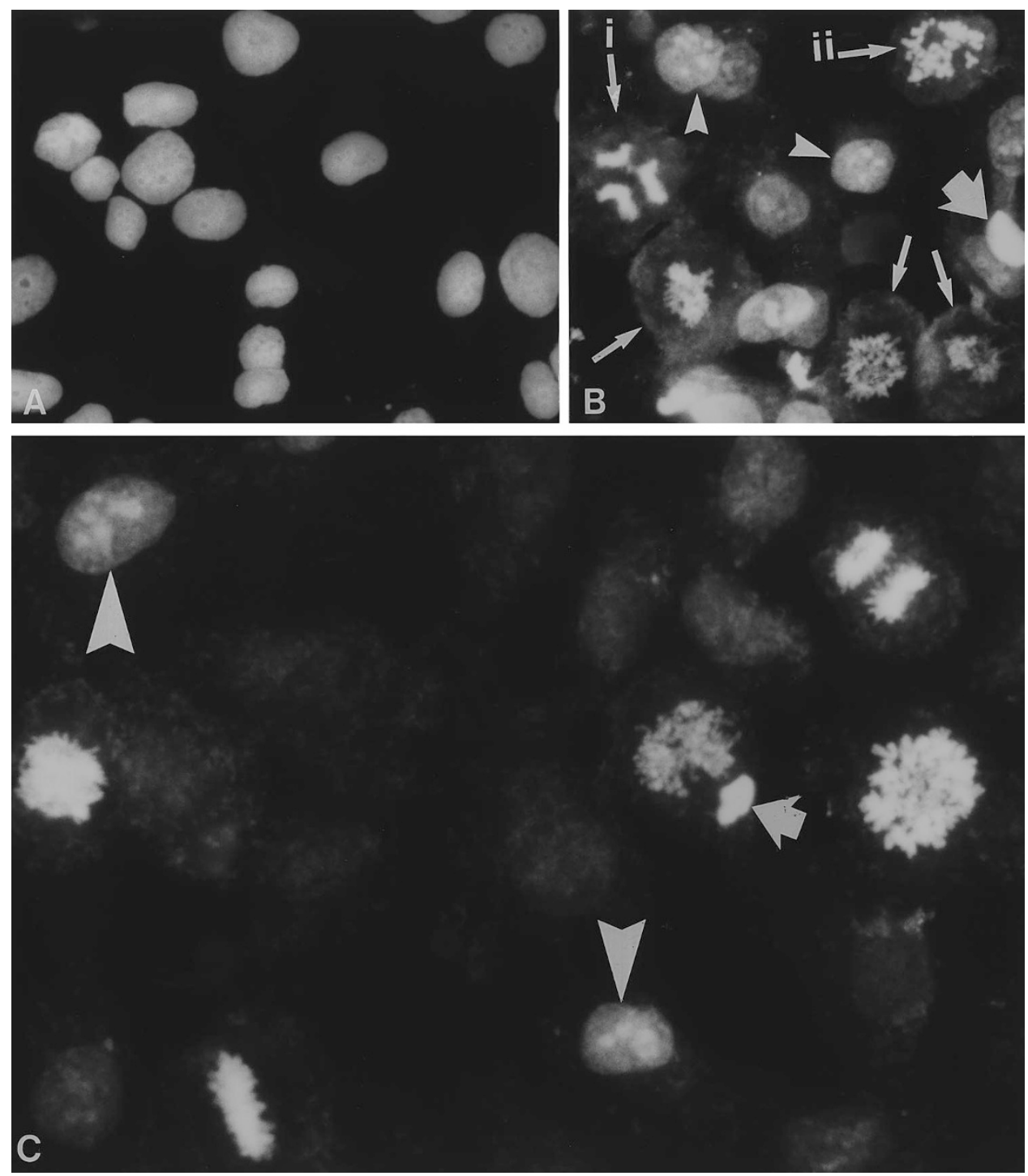

Figure 7 (A) PI-DNA binding cytological profile of the control state without $\mathrm{V}(4)$ prepulsing (obtained by Cytospinning an aliquot of the cell syspension that gave the cell cycle profile of Figure $6 \mathrm{~A}(\mathrm{i})$ ). (B) Experimental state $2 \mathrm{~h}$ after $\mathrm{V}(4)$ prepulse (obtained by Cytospinning an aliquot of the cell suspension that gave the cell cycle profile of Figure $6 \mathrm{~A}(\mathrm{v}))$. Mitotic cells are clustered with apoptotic cells. Five mitotic cells are indicated by thin arrows. Arrow-(i) points to a triradiate metaphase plate and arrow-(ii) points to disorientated distribution of metaphase chromosomes. Arrowheads point to nuclei with characteristic 'lumpy' apoptotic chromatin condensations. Fat arrow points to a dense 'single-ball' chromatin condensation which is also typical of apoptosis (Earnshaw, 1995). (C) Cytological profile of the experimental state shown in Figure 6A(vi). The majority of cells are ghost-like with poor PI-DNA binding consistent with the solitary sub-G1 peak seen in flow cytometric DNA profiling. Apart from the ghost-like cells, however, the population was characterized by two other morphologies, viz., (1) apoptotic cells with 'lumpy' chromatin condensations (arrowhead), and (2) mitotic cells. Fat arrow points to an abnormal anaphase cell containing a dense chromatin clump suggesting conjoint expression of mitotic and apoptotic condensations in the same cell. 


\section{Materials and Methods}

\section{Cell culture}

Monolayer cultures of Chang liver cells (ATCC CCL 13) were grown in Dulbecco's modified Eagle's medium (DMEM, Sigma, St Louis, USA) with $10 \%$ fetal calf serum (Biological Industries, Kibbutz, Israel). Parallel cultures were seeded in $25 \mathrm{~cm}^{2}$ flasks (Costar) at $3 \times 10^{5}$ cells/flask from stirred stock suspension and grown to near confluency. Protocol was as previously described (Sit and Wong, 1989).

\section{Nuclear Microscopy}

For nuclear microscopy, cultures were seeded on serum-prepulsed Pioloform film anchored by Permount over an aluminium target holder and processed as previously described by us (Sit et al, 1993).

\section{Vanadyl(4) prepulse}

$4 \mathrm{mM}$ vanadyl(4) oxide sulphate (Fluka, Switzerland) in an $\mathrm{NH}_{4} \mathrm{Cl}$ buffer ( $50 \mathrm{mM} \mathrm{NH}_{4} \mathrm{Cl}, 50 \mathrm{mM}$ glucose) was prepared by dissolving first in $\mathrm{H}_{2} \mathrm{O}$ and adjusted to $\mathrm{pH} 5.5$ using $4 \mathrm{~N} \mathrm{NaOH}$. Cells were given a 30 min prepulse $\left(37^{\circ} \mathrm{C}\right)$ in the $V(4)$ buffer, before reincubation in normal DMEM growth medium containing $10 \%$ foetal bovine serum. Protocol was as previously described (Sit et al, 1996a).

\section{Cellular localization of oxidative reactivity using redox indicator methylene blue}

After $\mathrm{V}(4)$ prepulsing, cells were fixed in $100 \%$ methanol and then stained for $3 \mathrm{~min}$ in $3 \mathrm{ml}$ aqueous methylene blue (Gurr, BDH, UK, $0.5 \mathrm{~g} \mathrm{mg} / \mathrm{ml}$ ) and air dried. In the reduced state methylene blue is colourless. When oxidized, methylene blue becomes metachromatic and appears purple. Protocol was as previously described (Sit et al, 1996b).

\section{Glutathione (GSH) evaluation}

Cells prepulsed with $\mathrm{V}(4)$ with or without recovery in normal DMEM growth medium had monochlorobimane (MCB, Molecular Probes, Eugene, Oregon, USA) added to their respective incubation medium to a final concentration of $40 \mu \mathrm{M}$ (stock solution $40 \mathrm{mM}$ in DMSO) and incubated at $37^{\circ} \mathrm{C}$ for $15 \mathrm{~min}$. MCB readily entered the cell to form GSH-MCB adducts, a reaction mediated by intracellular glutathione-Stransferase (GST). GSH-MCB fluoresces at the excitation/emission wavelength of $395 / 470 \mathrm{~nm}$. By itself, MCB is non-fluorescent. Protocol was as previously described (Sit et al, 1996b, Kane et al, 1993).

\section{Ratiometric BCECF measurement of intracellular $\mathrm{pH}\left(\mathrm{pH}_{\mathrm{i}}\right)$}

For measurement of $\mathrm{pH}_{\mathrm{i}}$, the cells were loaded with $10 \mu \mathrm{M} \mathrm{BCECF-am}$ (Molecular Probes) with detailed protocol as previously described (Sit et al, 1994).

\section{Detection of genomic DNA fragmentation by TUNEL}

Terminal deoxynucleotidyl transferase (TdT)-mediated dUTP nick endlabelling (TUNEL) highlights $3^{\prime} \mathrm{OH}$ termini of DNA fragmentation which are characteristic of apoptotic DNA fragmentation. The manufacturer's protocol (ApopTag, Oncor, USA) was followed. The principle involved was templete-independent addition of dUTP-digoxigenin to $3^{\prime} \mathrm{OH}$ ends of the fragmented DNA catalyzed by exogenous terminal deoxynucleotidyl transferase (TdT), which was followed by binding with fluorescein-labelled antidigoxigenin antibody for detection. Procedure was previously described (Sit et al, 1996b).

\section{Permeabilization of cells for propidium iodide binding and micrococcal nuclease digestion}

Single cell suspension of the monolayer culture was obtained by scraping with a Cell Scraper (Costar) and triturated using a $5 \mathrm{ml}$ syringe and a 21 guage needle. Permeabilization was achieved by resuspension in $1 \%$ Bouin's fluid (15 parts of $1.2 \%$ aqueous picric acid, five parts of formalin and one part of glacial acetic acid) in Dulbecco's phosphate buffered saline (PBS) for $1 \mathrm{~min}$, and then washed twice with $10 \mathrm{ml}$ of PBS. The permeabilized cells were still alive and when reseeded into the culture flask will grow to confluency, with neutral red viability test (Sit et al, 1992) showing increased uptake (27.4\% higher than the controls, as evaluated by flow cytometry) which was a reflection not of higher viability but of permeabilization without compromising viability.

\section{Propidium iodide-DNA binding}

Cells were permeabilized as described above, and incubated in $1 \mathrm{ml}$ of freshly prepared propidium iodide (PI, Sigma, St louis, USA) solution (Tris $1.21 \mathrm{~g} / \mathrm{l}, \mathrm{NaCl} 0.589 \mathrm{~g} / \mathrm{l}, \mathrm{PI} 0.050 \mathrm{~g} / \mathrm{l}$ ) which contained $30 \mathrm{mg}$ ribonuclease A (RNase A, Type IIA, Sigma) per $5 \mathrm{ml} \mathrm{PI} \mathrm{solution,} \mathrm{added}$ just before incubation. Incubation time was $45 \mathrm{~min}$ over an ice bath. Cells were pelleted by centrifugation and washed with PBS. For cytological profiling, a $50 \mu \mathrm{l}$ aliquot of the cell suspension was Cytospinned onto slides (Cytospin-2, Shandon, UK) for examination under the Reichert-Jung Univar fluorescence microscope at excitation/ emission wavelength of $510 / 630 \mathrm{~nm}$. The rest of the cell suspension was used by the Coulter EPICS ELITE ESP flow cytometer for cell cycle evaluation. The Coulter Elite Workstation programme version 4.0 was used. For DNA cell cycle analysis the bundled Multicycle software version 2.53 was used.

\section{References}

Abend M, Gilbertz KP, Rhein A and van Beuningen D (1996) Early and late G2 arrest of cells undergoing radiation-induced apoptosis or micronucleation. Cell Prolif. 29: $101-113$

Briehl MM and Baker AF (1996) Modulation of the antioxidant defence as a factor in apoptosis. Cell Death Differ. 3: 63-70

Byrnes RW (1996) Evidence for involvement of multiple iron species in DNA singlestrand scission by $\mathrm{H} 2 \mathrm{O} 2$ in HL-60 cells. Free Rad. Biol. Med. 20: 399-406

Dawson VL and Dawson TM (1996) Free radicals and neuronal cell death. Cell Death Differ. 3: $71-78$

Earnshaw WC (1995) Nuclearchanges in apoptosis. Curr Opin. Cell Biol. 7: 337-343

Evan GI, Brown L, Whyte M and Harrington E (1995) Apoptosis and the cell cycle. Curr. Opin. Cell Biol 7: 825-834

Farber JL, Kyle MR and Coleman JB (1990) Biology of disease: Mechanism of cell injury by activated oxygen species. Lab. Invest. 62: 670-679

Fernandez A, Kiefer J, Fosdick L and McConkey DJ (1995) Oxygen radical production and thiol depletion are required for $\mathrm{Ca} 2+$-mediated endogenous endonuclease activation in apoptotic thymocytes. J. Immunol. 155: 5133-5139

Gazitt Y and Erdos GW (1994) Fluctuations and ultrastructural localization of oncoproteins and cell cycle regulatory proteins during growth and apoptosis of synchronized AGF cells. Cancer Res. 54: 950-960

Halliwell B and Gutteridge JMC (1984) Oxygen toxicity, oxygen radicals, transition metals and disease. Biochem. J. 219: 1-4 
Hamada T (1994) Vanadium induced hemolysis of vitamin E deficient erythrocytes in Hepes buffer. Experientia 15: 49-53

Harrington EA, Fanidi A and Evan GI (1994) Oncogenes and cell death. Curr. Opin Genet. Devel. 4: 120-129

Hartwell LL and Kastan MB (1994) Cell cycle control and cancer. Science 266: 1821 1827

Kane DJ, Sarafian TA, Anton R, Hahn H, Gralla EB, Valentine JS, Ord Tand Bredesen (1993) Bcl-2 inhibition of neural death: Decreased generation of reactive oxygen species. Science 262: $1274-1276$

Keller J, Sharma RP, Grover TA and Piette LH (1988) Vanadium and lipid peroxidation: Evidence for involvement of vanadyl and hydroxyl radical. Arch. Biochem. Biophys. 265: 524-533

Khan AA, Soloski MJ, SharpAH, Schilling G, Sabatini DM, LiSH, Ross CA and Snyder SH (1996) Lymphocyte apoptosis: Mediation by increased type 3 inositol 1,4,5trisphosphate receptor. Science 273: 503-507

King KL and Cidlowski JA (1995) Cell cycle and apoptosis: Common pathways to life and death. J. Cell. Biochem. 58: 175-180

Piacentini M, Fesus L and Melino G (1993) Multiple cell cycle access to the apoptotic death programme in human neuroblastoma cells. FEBS Lett. 320: 150-154

Reddy KB (1996) Epidermal growth factor induced apoptosis. Apoptosis 1: 33-39

SitKH, Bay BH and Wong KP (1992) Distinctive uptake of neutral red by mitotic cancer cells. Biotechn. Histochem. 67: 196-201

Sit KH, Bay BH, Paramanantham R, Thong P and Watt F (1993) Preparation of monolayer cultures for nuclear microscopy. J. Tissue Cult. Meth. 15: 199-203

Sit KH, Paramanantham R, Bay BH, Wong KP: Azide- and vanadate-sensitive Mphase alkalinity and cytosolic acidification of Chang liver cells. Jpn. J. Pharmacol. 65: 83-87 (1994)
SitKH, Paramanantham R, Bay BH, Chan HL, Wong KP, Thong P and WattF (1996a) Sequestration of mitotic (M-phase) chromosomes in autophagosomes: mitotic programmed cell death in human Chang liver cells induced by an $\mathrm{OH}^{*}$ burst from vanadyl(4). Anat. Rec. 245: 1-8

Sit KH, Paramanantham R, Bay BH, Wong KP, Thong P and Watt F (1996b) Induction of vanadium accumulation and nuclear sequestration causing cell suicide in human Chang liver cells. Experientia 52: 778-785

SitKH and Wong KP (1989) Induced interphase cell retractions: Its reversal and EGF potentiation. Tissue Cell 21: 321-333

Slater AFG, Stefan C, Nobel I, van den Dobbelsteen DJ and Orrenius S (1996) Intracellular redox changes during apoptosis Cell Death Differ. 3: 57-62

Sundaresan M, Yu ZX, Ferrans VJ, Irani K and Finkel T (1996) Requirement for generation of $\mathrm{H} 202$ for platelet-derived growth factor signal transduction. Science 270: 296-299

Thompson CB (1995) Apoptosis in the pathogenesis and treatment of disease. Science 267: $1456-1462$

Tounekti O, Belehrader JJr and Mir LM (1995) Relationships between DNA fragmentation, chromatin condensation, and changes in flow cytometry profiles detected during apoptosis. Exp. Cell Res. 217: 506-516

Traganos F, Ardelt B, Haiko N, Bruno S and Darynkiewicz Z (1992) Effects of genistein on the growth and cell cycle progression of normal human lymphocytes and human leukemic MOLT-4 and HL-60 cells. Cancer Res. 52: 6200-6208 